\title{
THE NEGATIVE IMPACT OF NIAS LANGUAGE INTERFERENCE IN LEARNING INDONESIAN LANGUAGE
}

\author{
Evi Eunike Mendrofa \\ Fakultas Manajemen Pertahanan, Universitas Pertahanan \\ email: evieunike21@gmail.com
}

\begin{abstract}
Most of people in the world and also Indonesian speakers are bilingualism, who use two languages; Indonesian and mother tongue. Commonly, both languages influence one another, which finally create a new phenomenon of language called interference of language. Interference of language is a form of an impact of mother tongue towards second language, which creates an error in the second language. The error occurs because the mother tongue language and the second language have different structure and different way in using the language.

In this research, the writer finds out that the ability of someone in mastering the second language will always be influenced by the mother tongue. As a real case for Nias speakers, they make mistakes and errors when they speak in Indonesian, especially in phonological and grammatical structure. The mistake occurs because phonological and grammatical in their mother tongue are still used in second language, thus it makes the second language invalid in the way of norm and rule.

From the result of the research, it can be concluded that Nias speakers interfere Indonesian in their daily conversation. The interference can be existed as a form of the impact of mother tongue to second language. In this research, there are three interferences of Nias speakers that have been found by the writer. First, Nias speakers omit the final consonant of words when speaking in Indonesian, it is because in Li Niha there is no final consonant of words but only final vowel. Second, Nias speakers also create a redundancy when they are speaking Indonesian, it is because they are usually add some words in their speech in order to emphasize their statement. Third, Nias language and Indonesian language have different structure in arranging sentences. Based on that difference, Nias speakers oftentimes invert the words in sentences. So, the writer concluded that all of these aspects are the aspect which influences Nias speakers to interfere the second language.
\end{abstract}

Keywords: Sociolinguistics, Interference, Mother tongue, Bilingualism, Phonological, Grammatical structure..

\section{INTRODUCTION}

Most of Indonesian people are able to speak more than one language. It means that Indonesian people are bilingualism.
Weinrich (1970: 64 - 65) states that interference is a general problem that occurs in bilingualism. Therefore, some problems exist about mastering the languages. The ability for mastering the 
second language is often influenced by mother tongue of the speaker. This kind of case was called as an interference of languages. Interference of language appear because of people who lack of fluency. For mastering the second language a person will never be free from their first language, it means that the second language will be affected by the first language. This kind of interference case is experienced by people's mother tongue.

On the other hand, Lott (1983: 256) states that interference is also known as an error effect on the production of the language being learned. The effect can be on any aspects of language: grammar, vocabulary, accent, spelling and so on. It is most often discussed as a source of errors (negative transfer), although where the relevant feature of both languages is the same, it results in correct language production (positive transfer). The greater the differences between the two languages, the more negative the effects of interference are likely to be. It will inevitably occur in any situation where someone has not mastered a second language.

\section{THEORETICAL FRAMEWORK}

Bilingualism is a worldwide phenomenon. Most nations have speakers of more than one language. A bilingual person is someone who speaks two languages. Many bilingual speakers have learned their two languages at the same time, usually in early childhood and as a result of family bilingualism. These people are called simultaneous bilinguals. According to William F. Mackey (1970: 239) one of the most obvious effects of bilingualism is the interference of one of the bilingual languages with his use of the other.

There are 2 among the five types of Interference according to Jendra (1991: 108): Phonological Interference \& Syntactical Interference.

In phonological level, the problem of interference concerns about the manner when a speaker produces or reproduces the sounds of one language to another 
language. This interference occurs in the speech of bilingual as a result of the fact that there are different elements in sound system between first language to the second language and or between native languages to the foreign languages. One of phonological interference in language is omission of final consonant. This interference occurs in the speech of bilingual as a result of the fact that there are different elements in sound system between first language and second language or between native languages to the foreign languages. The errors occur unintentionally in the time of speech and as the result the speaker omit the final consonant of the words.

There are some reasons of the interference existence. The first reason is the existence of a given sound in the latter, which is not found in the former. For example : in Li Niha there is no consonant at the end of the word such as "hezo, mofano, manga, mondri, mangawuli," etc, meanwhile in Indonesian in some words there is a consonant at the end of the word such as "kencan, masak, rapat, sesak, jalan" etc. This difference influences Nias speaker when they speak in Indonesian, as a result they will omit the consonant in every end of the words.

Second reason is, both languages have the same phonetic features but they are different in their distribution, namely: when and where they may occur in an utterance. Having a different distribution in language will be brought when the speaker speaks in his second language.

Third reason is, both languages have similar sounds that have different variants or allophones. Interference arises when a bilingual speaker identifies a phoneme of one language in another language. For instance, an Indonesian speaking English may pronounce bag as [bæk] instead of [bæg]. This interference occurs because of the fact that /g/ never arises in the final position of Indonesian language words; so, /g/ is identified as /k/ in that position. In addition, he may replace 
/v/ with /p/, /f/ with /p/; he may not use a /p/ with aspiration. In Li Niha they will pronounce the words correctly and properly such as /kh/ and /z/: "akhir zaman" meanwhile in Indonesian speaker they don't mention $/ \mathrm{kh} /$ but it will be mention like/k/ "akir" and for the /z/ it will be mention like / $\mathrm{j}$ / "jaman. This case is also brought when Nias speaker speak Indonesian, they will pronounce the words correctly.

The influence of native language interference can occur in different situations while they are speaking. It is strongly believed that linguistic interference is one of the fundamental difficulties faced by the learners of second languages. Judging by the experience we can assume that problems are mainly caused by the lack of substantial knowledge of lexical and grammatical structures and aspects of the target language.

Mother tongue is a traditional term for a person's native language that is a language learned from birth. It is also called as first language, dominant language, home language, and native tongue (although these terms are not necessarily synonymous). Romaine (1989: 12) says "Interference can be as a result of incomplete acquisition. Interference can occur when a bilingual starts to use the two languages he has acquired separately". So, the mother tongue play role in first speaker when they learn the second language.

\section{RESEARCH METHOD}

In this research, the writer uses a qualitative research because it is an appropriate method related with the project.

This research describes the interference cases in Li Niha to Indonesian language. The writer observed some people from Nias who live in Semarang and the writer also gather some data directly in location (Nias Island). As supporting data, the writer also takes some 
Nias songs. Therefore, in this chapter the writer will explain further about the data. The data are data recording and uses Nias songs to show the reader the characteristic of Nias language.

In analyzing this research the writer use qualitative research because it is the most appropriate method related with the case.

\section{DISCUSSION}

Phonological Interference

Omission of final consonant

\section{Data 1 :}

"Mereka bila mmm liha si dian itu sombo bange mereka engga mau bertema sama kita lagi mereka sombo - sombo bange".

In the sentence above, the speaker omits the final consonant of words. The speaker omits final consonant "ng" for "sombo", " $\mathrm{t}$ " for "bange" and " $\mathrm{n}$ " for "bertema". The words should be "sombong" with final consonant of "ng", "banget" with final consonant of " $\mathrm{t}$ " and "berteman" with final consonant of " $n$ ".
The speaker interferes Indonesian by omitting the final consonant of words and says "sombo bange" and "bertema" and repeat again with omission "sombo sombo bange". In this conversation, the speaker has not mastered Indonesian yet and she is not used to speak Indonesian. Even though, the speaker is trying to speak Indonesian as fluent as possible but still ended with omission. The speaker should pay more attention when there is a final consonant of words like "sombong banget" and "berteman". This case is supported by Nias song. Through this song, we can see if the word in Li Niha is never ended with a final consonant but always ended with a vowel. in $\mathrm{Li}$ Niha the phonemic form is CVCV (consonant - vowel - consonant vowel) or VCV (vowel - consonant vowel), here are the following sample of words in Li Niha, uses Nias song :

Tanõ Niha banua somasido (Pulau Nias pulau yang ku cinta) Tanõ situmbu ya'o fõna (Tanah tempatku dilahirkan) 
He mukoli ndra'o bazarõu

(Walau jauh di rantau orang)

Balõ olifudo sa'ia

(Namun kau tak dapat kulupakan)

Tanõ situmbu do

(Tanah tempatku dilahirkan)

Mohili wa'ebolo ndraso

(Sawah ladang luas menghijau)

Sonungo nidañ̃ ba mbombo

(terdapat sumber mata air di

sungai kecil)

Fasui asi sebolo

(dikelilingi oleh laut yang luas)

Data 2:

"kamu janga lupa kasitau sama tema - tema kita”

In $\mathrm{Li} \mathrm{Niha}$, there is no final consonant of words because all the words ended with vowel. Just like in the sentence above, the speaker omits final consonant " $\mathrm{n}$ " for "janga and tema". The words should be "jangan" and "teman" with final consonant " $n$ ". The speaker omits final consonant is because the speaker has affected by the mother tongue of Nias language which never have final consonant in words but final vowel. That is why the speaker omits final consonant when speak Indonesian and it will occurs in the time of speech or conversation accidentally and intentionally. Omission is one of errors that frequently occur from Nias speakers.

Data 3:

"Kamu peli bange jadi ora"

There is omission in the sentence above, the speaker omits final consonant " $t$ " in "peli", "bange", and consonant " $n g$ " in "ora". The words "peli", "bange", "ora" need a final consonant to avoid weird and awkward words. The good words should be "pelit", "banget", "orang" with final consonant " $t$ " and "ng". In this case, Nias speakers are difficult to complete every final consonant in words because they get used to end words with a vowel in Li Niha (Nias language). At this point, they will omit words unconsciously and spontaneously in the time of speech. This is one of the influences of mother tongue to second 
language which is always brought in the second language and as the result interfere the second language.

Data 4:

\section{"Lebi banya ya kamu tolo"}

When Nias speakers speak in Indonesian, they will omit final consonant of the word. Just like in the sentence above, the speaker omits final consonant " $h$ " in "lebi" word, " $k$ " in "banya" word, " $n g$ " in "ya" and "tolo" word. The good words should be "lebih" with final consonant of “ $h$ ", "banyak" with final consonant of " $k$ ", and "yang", "tolong" with final consonant of " $n g$ ". So, the sentence should with a final consonant like "lebih banyak yang kamu tolong". To complete final consonant in every words, is a difficult thing for Nias speakers.

Data 5:

\section{"Kemari aku maka gorenga"}

In the sentence above definitely people will know if the speaker is Nias speaker because there is omission in words, like in the sentence above. The speaker omits final consonant " $n$ " in "kemari", "maka", "gorenga" word. The good words should be "kemarin", "makan", "gorengan" with final consonant " $n$ ". For Nias speakers, it is not a big deal when they omit final consonant of words but nonetheless they want to avoid it. Instead, they are never able to avoid it. Omission occurs intentionally in the time of speech or conversation which makes Nias speakers sound awkward when speaking in Indonesian. As the result, it influences Nias speakers when speak Indonesian and ended with omission. It is not impossible for Nias speaker to speak Indonesian fluently but it need times to adjustability.

Data 6:

"Saya cenderu memakai kata upa"

In the sentence above, the speaker omits final consonant " $n g$ " in "cenderu" word and " $h$ " in "upa" word. The correct word should be "cenderung" with final consonant " $n g$ " and "upah" with final consonant " $h$ ". Then, the good sentence 
should be "saya cenderung memakai kata upah". Omission occurs unconsciously and spontaneously in the time of speech, as long as he or she is Nias speakers. In the sentence above, the speaker is trying to speak as fluent as possible but instead ended with omission. It happens as influences of their first language (Li Niha) because in $\mathrm{Li}$ Niha there is no final consonant in words but final vowel. As the result, Li Niha interfere the speaker by omitting final consonant when they speak Indonesian.

Data 7:

\section{"Buka seperti itu maksu ku"}

In the sentence above, omission occurs in the time of conversation. The speaker omits the words "buka and maksu", the correct words should be "bukan and maksud" with final consonant " $n$ " for "buka" and " $d$ " for "maksu" word. Omission is not a new error for Nias speakers but almost every time they speak in Indonesian, they omit final consonant intentionally and ended up with vowel. It is one of the negative impacts of the mother tongue to the second language. The form of Li Niha (Nias language) influences Nias speakers when speak Indonesian and as the result interfere Indonesian. Therefore, in this sentence the speaker should pay more attention in order to avoid the omission. So, the sentence should be "bukan seperti itu maksud ku".

Data 8:

"bia kami juga tau kapa kami latiha"

The speaker makes the same mistakes as discussed previously about omission. The speaker omits the words "bia, kapa and latiha" which should be "biar" with final consonant "r", and "kapan and latihan" with a final consonant " $n$ ". The reason why the speaker omits the consonant is because the speaker is lack of fluency to speak well in Indonesian. It happens because the speaker has not master Indonesian yet and the speaker does not used to speak Indonesian. This situation can occur in any situation formal or informal and Nias speakers are not 
intentional do it (omission) but it happens accidentally in the time of speech.

Data 9:

"Sampai masyaraka juga bisa terbantu"

In Li Niha (Nias language) there is no consonant in every end of the words because it always ended by vowel. In the sentence above, there is omission in "masyaraka". The word should be "masyarakat" with final consonant of " $t$ ". In the sentence above, the speaker omits final consonant intentional without realizing it. Omission is often occurs when Nias speakers speak in Indonesian. It is one the negative impacts of the mother tongue (Li Niha) towards the second language (Indonesian). The form of the word in $\mathrm{Li}$ Niha has brought to Indonesian, with no final consonant but final vowel. As the result, the speaker omits the consonant and ends it with vowel. In this case, the speaker should improve his language skill (Indonesia).

Data 10:

"Kami masi butu tenaga kerja"
In the time of speech, the speaker omits some final consonant in the words. When the speaker says "masi butu", the speaker omits final consonant " $h$ ", the word should be "masih butuh". These mistakes always occur unintentional and it makes the conversation sounds awkward. Usually, Nias speakers are difficult to complete final consonant in every end of words when speak Indonesian. It happens because they get used to speak Li Niha without final consonant of words but always ended with vowel. So, although Nias speakers get used to speak Indonesian but Li Niha (Nias language) still affected them when speak Indonesian. As the result, Nias speakers interferes their second language or Indonesian.

\section{Syntactical Interference}

Redundancy

Data 1:

“Ongko - ongko testi aja sampe 15 - 16 kali testi kok”,

Nias speakers tend to use additional information to clarify a 
sentence, but sometimes they create ineffective sentence due to waste of elements. In the sentence above, the speaker repeat the noun "ongko" (ongkos) and the verb "testing" all at once in a sentence and it makes redundant. The speaker is trying to make the sentence more complete by repeat the same words. Instead, the speaker makes the sentence ineffective and sounds rambling. The word "ongko" (ongkos) and "testi" (testing) does not need to be repeated, because when there is noun followed by verb the sentence has become good form according to Indonesian grammatical structure and the sentence is understandable towards the listener. Therefore, the speaker should make the effective sentence "ongko testi aja sampai 15 - 16 kali”. Redundancy occurs as an impact of the first language or Nias language because in Li Niha some words is need to be repeated in order to emphasize the speaker means. As the result, the speaker brought it into
Indonesian language which finally ended up with redundancy.

\section{Data 2:}

“Mereka engga mau bertema sama kita lagi mereka sombo - sombo bange”

In the sentence above, the object "Mereka" and the adjective "sombo" (sombong) do not need to be repeated. It happens because the speaker wants to give more explanation about the object and to make her sentence to be more complete. In Li Niha there is a repetition of some words, which finally influences Nias speakers to repeat the words in Indonesian. The speaker adds some unnecessary words in this sentence which make it ineffective and as the result the words redundant. Actually, the object "Mereka" only one occurs in a sentence and no need to repeat. The adjective "sombo" (sombong) does not need to be repeated twice because after the adjective there is an adverb followed "bange" (banget) and it is enough to emphasize the adjective. The phrase should be 
"sombo bange" not "sombo - sombo bange". Therefore, the better sentence should be "Mereka sombo bange dan engga mau lagi bertema sama kita".

Data 3 :

"Mau cari - cari kerja, maunya di koperasi”

Nias speakers get used to do repetition in their speech or conversation. In the sentence above, the speaker repeat verb "cari" and repeat "mau" word. Actually, the word "cari and mau" does not need to be repeated twice or more in a sentence because it can cause redundancy. Instead, the speaker repeats the same word five times and makes the sentence redundant. The sentence will be more effective and simple if the speaker put the word "cari and mau" one in a sentence. The more effective sentence should be "mau cari kerja di koperasi". The redundancy occurs because the speaker wants to emphasizing her sentences instead, it ended up so rambling. The error in the sentence above is not a big deal and the listeners can understand as well, but still according to Indonesian rules there are some wasted of elements in the sentence. Therefore, the speaker should pay more attention towards his or her speech in order to avoid the redundancy of language. Redundancy is one of the influences of mother tongue (Nias language) towards Indonesian language. It is because in $\mathrm{Li}$ Niha (Nias language) repeating some words in conversation or speech is necessary. As the result, Nias speakers interfere Indonesian.

Data 4:

\section{"Masi belum tau wõgõi juga bale"}

Nias speakers used to add some words in their speech or conversation while speaking, instead it becomes redundant. Like in the sentence above, redundancy occurs when the speaker says "belu tau wõgõi juga", the word "wõgõi" means "juga". So, the meaning of the sentence if in Indonesian is "belu tau juga juga". Definitely, the word is redundant because there are two words with the same 
meaning occur in the sentence. Actually, the speaker does not need to repeat that word because they have the same meaning. It happens because Nias speakers have habits to mix Li Niha (Nias language) when speak in Indonesian, and the speaker does not realize if she already repeat the same words in her speech. The speaker should not mix the language when speak in Indonesian because it will makes the sentence redundant. So, the good sentence should be "masi belu tahu juga" without adding the word "wõgõi and bale". Although, redundancy is a simple error in language but it can break the rule of the language.

Data 5:

"biar aku piki-pikirka dulu bale"

In the sentence above, there is a redundant word adding by the speaker. The speaker says "aku piki-pikirka dulu bale", actually the verb "piki" (pikir) does not need to be repeated twice in a sentence because normally it is only one occur in a sentence. If the speaker adds more than one verb, it should be a different verb not the same verb. The verb "pikirka" (pikirkan) is enough to emphasizing the activity of the speaker. In this sentence, the speaker adds some words in her speech without realizing it and makes the sentence redundant. The more effective sentence should be "bia aku pikirka dulu" without repeating the verb "piki" (pikir) and no need to add the adjective "bale" because "bale" is Nias language. The habit to mix both of languages always brought by Nias speakers and finally it makes the speech rambling and difficult to be understood by the listeners. In the sentence above, the speaker has not master Indonesian yet that is why she mixed the language. Actually, redundancy is not a big error in language but it makes the sentence rambling and difficult to be understood. The reason why Nias speakers add some repetition when they speak Indonesian is because in $\mathrm{Li}$ Niha they used to repeat some words in order to emphasize their statement. Meanwhile, in Indonesian there is no 
repetition of words unless special words like "melayang - layang". So, Nias speakers should pay more attention in order to avoid redundancy of the language.

Data 6:

"iyala tapi janga beso tapi ya pastinya"

Definitely, once we take a look at the sentence above we know if there is a redundant of the words. The speaker repeats the conjunction "tapi" twice in the sentence. Actually, in the sentence the conjunction does not need to be repeated because normally it is only one occur in a sentence and the function of conjunction is to connect the first phrase to the second phrase. In fact, in this sentence there is no phrase that needs to be connected to another phrase because the speaker wants to make sure about the time and trying to contrast the word between "iya" and "tapi". It is enough by saying "iyala tapi janga beso (jangan besok) pastinya" without adding the conjunction "tapi" anymore. Nias speakers tend to use additional information to clarify sentences, but sometimes they creates ineffective sentence due to waste of elements. Instead, the sentence becomes redundant. It happens as influences of the mother, because in $\mathrm{Li}$ Niha they used to do repetition. As the result, it brought by the speaker when speak in Indonesian without realizing if the words has undergone of repetition.

Data 7:

"sudahla ngga usa banya canda - canda kita"

In the sentence above, Nias speakers create ineffective sentence by adding twice the verb "canda" in the sentence. Actually, the verb "canda" does not need to be repeated because by saying "canda" the listeners have known what the speaker means. In Li Niha, it is normal to repeat the verbs like "canda - canda" or "mai - mai" in Li Niha, but in Indonesian the verb "canda" normally does not need to be repeated. As the result, Nias speakers make the sentence ineffective and waste some elements of words. So, the effective 
sentence should be "sudahla, tida usa banya canda (tidak usah banyak canda)" Sometimes, Nias speakers try to emphasize their statement by adding more verb in their speech, instead the speaker makes it redundant. As discussed above, the word "canda - canda" is normally repeated twice in Nias language by saying "mai - mai". So, the reason why Nias speakers make a mistake by repeating the words is because they used to do repetition in their own language (Nias language) which finally brought to the second language (Indonesian language). In the other hand, Nias speakers has getting influences by the mother tongue and as the result the speaker interfere the second language (Indonesian language)

Data 8:

\section{"Pikiraku suda pusi saya"}

Once the listeners heard the speech, they will know if the sentence is redundant. The redundancy occurs when the speaker says "pikiraku" (pikiranku) and then says "suda pusi saya" (sudah pusing), he repeats the subject "- $a k u$ " and "saya" all at once in the sentence. After possessive pronoun "pikira - ku", the speaker adds the subject "saya" at the end of the speech. Actually, in the sentence above no need to add the subject "saya" because possessive pronoun already put the subject inside the phrase "pikira $a k u$ ". Furthermore, the phrase "pikira $k u$ " is not suitable either with subject " $a k u$ " because noun "pikira" (pikiran) does not belong to possessive pronoun. It is better if the speaker says "saya suda pusi" than says "pikiraku suda pusi (pikiranku sudah pusing", because the first phrase is more suitable than the second phrase. In the sentence above, the speaker does not realize if he already make a mistake by adding more than one subject of " $a k u$ and saya". It happens because the speaker wants to explain clearly about the subject condition, instead it becomes redundant. This case, usually occur in Nias speakers while speak Indonesian because they like to explain something superfluous and add 
some unnecessary explanation in speech.

Moreover, in Li Niha (Nias language) they

normally do repetition in their language

like "mai - mai" or "candaan" in

Indonesian language. Therefore, Nias

speakers make a sentence redundant

because they have been getting influences

by their mother which ended up with

redundancy and interfere Indonesian

language.

Data 9:

“aba dari mana aba”

The sentence above is redundant.

The speaker says "aba (abang) dari mana aba (abang)" by repeating the same object "aba (abang)". Actually, there is no need for the speaker to repeat the same object "aba (abang)" because by saying it once the listeners have known the speaker means. Instead, the speaker does repetition and ended up with redundancy. So, a good sentence should be "aba (abang) dari mana" or "dari mana aba (abang)". It may be the speaker does not purpose to do repetition, but because the speaker has getting influences by Li Niha, she makes the sentences redundant.

Data 10:

"mau bawa ole - ole, misalka makana Nias misalka"

In the sentence above there is a redundancy of words because the repetition of the same words in the sentence. The speaker makes everything redundant, when he repeats the word "misalka (misalkan)" twice in conversation. Absolutely, the speaker does not need to repeat it because the word "misalka (misalkan)" normally only one occurs in a sentence. It is better if the speaker just saying it once, in that way the sentence will be more effective and not rambling. So, the sentence should be " $m a u$ bawa ole-ole, misalka makana Nias". The speaker causes redundancy in speech or conversation is because they had been get influences by their mother or Li Niha. In $\mathrm{Li}$ Niha (Nias language) repetition is necessary for some words for example "molaya - laya" or "melayang" in 
Indonesian. As the result, the speaker is interfere Indonesian by causing redundancy. Absolutely, redundancy is not a fatal error of language but still is not accordance with the grammar. Moreover, the sentence will be sounds rambling and difficult to be understood by the listeners.

Data 11:

"Sehiga ora - ora masyaraka juga bisa terbantu"

A habit to put additional words in speech, it makes Nias speakers rambling when speak Indonesian. Just like in the sentence above, the speaker repeats the same object "ora - ora and masyaraka". Actually, it is not necessary for the speaker to add two objects in the sentence. It will be effective and correct if the speaker puts one object in the sentence, if the speaker uses "ora - ora (orang - orang)" then directly should be followed by adverb not followed by object "masyaraka (masyarakat)" anymore. The speaker does not realize if he already repeats the same object all at once in the sentence. The object "ora-ora and masyaraka" have the same meaning and there are no differences between them. So, the speaker should not use both of the objects which caused a redundancy. Therefore, the correct and the effective sentence should be "sehingga masyaraka juga bisa terbantu". Redundancy is one of the influences of mother tongue (Nias language) towards Indonesian. It happens because in Li Niha (Nias language) repeating some words is necessary. As the result, Nias speakers are interfere Indonesian.

Data 12:

\section{"Apalagi ora menjadi seora dokte"}

In the sentence above, the speaker creates redundancy in the time of speech. The sentence becomes rambling when speaker repeated the noun "ora and seora" twice in the sentence. The noun "ora and seora (orang - seorang)" is the same thing and does not need to be repeated or to explained. Furthermore, the phrase “apalagi ora (orang)" followed by phrase "menjadi seora (seorang)" does not related 
to each other and it sounds weird. The proper phrase should be "apalagi seseora ya ingi menjadi dokte (seseorang yang ingin - dokter)", with a correct grammatical structure of Indonesian. In that way the sentence will be more effective and not rambling. In this case, the listeners may be understood the speaker means but nonetheless it is not a good and a correct sentence according to Indonesian grammatical rule as well. The error in arranging a sentence is one of mistakes that often occurs because Nias speakers sometimes does not realize if the things they have explain is just the same thing and does not need to be repeated. It happens because Nias speakers still affected by their mother tongue of Li Niha and as the result it interferes them when speak Indonesian.

\section{Grammatical Structure}

Nias speaker usually makes sentences with this pattern "Ket + Subject

+ Predicate" meanwhile in Indonesian grammatical rule is "Subject + Predicate

+ Object + Ket”.

Data 1 : "Tida tau kami juga wo"

Data 2 : "Apa gosi mereka?"

Data 3 : "Mereka ngga mau bertema sama kita lagi mereka sombo - sombo bange”

Data 4 : “Lõ (tidak) bisa aku”

Data 5 : "kapa latiha kita?"

Data 6 : “Kapanya mau pulang?"

Data 7 : "Tida bisa mereka katanya"

Data 8 : "Kan aku baru kasitau kalia"

Data 9 : "Kemana pergi kamu?"

Data $10 \quad$ : "dari mana kamu tadi"

Data $11 \quad$ : "dikasi kue sama kami lo tadi”

Data 12 : "ngapai disana kamu ba"

Data 13 : "kerja dimana sekara kamu”

Data 14 : “tida mau kesana aku”

Data 15 : "tida bole kamu begitu”

Analysis

Data 1 :

“Tidak tahu kami juga" (Li Niha) Nias language 
Adv

Subject Predicate

\section{"Kami \\ juga \\ tidak \\ tahu” (Indonesian) \\ Subject Predicate \\ Adv \\ "We don't know as well"}

(Meaning)

In Li Niha (Nias language) the pattern

in making a sentence is different from

Indonesian. As the data above, in Li Niha the adjective phrase should be adverb followed by subject ( $\mathrm{adv}$ - subject)

"Tidak tahu

kami

juga”

Adv

\section{Subject Predicate}

Meanwhile Indonesian grammatical rule is

subject followed by predicate (subject predicate)

"Kami

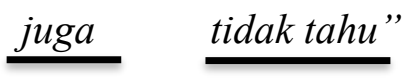

Subject

Predicate

Adv

As the impact of grammatical structure differences between $\mathrm{Li}$ Niha (Nias Language) and Indonesian language, the speaker (Nias speakers) automatically interfere Indonesian language when he or she speaks Indonesian and the sentence will be ungrammatical according to Indonesian grammatical rule.

Data 2 :

“Apa gosip mereka?”

(Li Niha) Nias language

Aux V Verb Object

“Apa yang mereka gosipkan?”

(Indonesian)

\section{Aux V Object Verb}

\section{"What are they talking about?"}

(Meaning)

In Li Niha the pattern in making the interrogative sentences should be auxiliary verb followed by verb $($ aux $v-v)$

$\frac{\text { "Apa }}{\text { Aux V }} \quad \frac{\text { gosip }}{\text { Verb }} \quad \frac{\text { mereka" }}{\text { Object }}$

Meanwhile Indonesian grammatical rule of interrogative sentence should be subject followed by verb then the last followed by $\operatorname{aux} \mathrm{v}(\mathrm{s}-\mathrm{v}-\operatorname{aux} \mathrm{v})$

"Apa yang mereka gosipkan?" Aux V Object Verb

As the result, Li Niha (Nias language) interfere Indonesian. In making interrogative sentences in Li Niha it starts 
from auxiliary verb followed by verb, but

in Indonesian interrogative sentences will

always start from subject then followed by

auxiliary verb. It may be understandable

towards the listeners but according to

Indonesian grammatical structure the

sentence has break the rule.

Data 3 :

“Mereka

nggak mau bertema sama

kita lagi” (Li Niha)

"Subject

Predicate

Object Adverb”

"Mereka

sudah tidak mau berteman

lagi sama kita” (Indonesian)

"Subject

Predicate

\section{Object”}

"They do not want to get along with us anymore" (Meaning)

In $L i$ Niha to make the sentence it should from Adverb followed by Subject, but in this sentences the speaker makes sentences from Subject followed by Predicate, it shows that the speaker is trying to follow the rule of Indonesian grammatical structure but still Li Niha interfere Indonesian. We can see it from the sentence $(\operatorname{subj}-$ pre $-o b j-a d v)$

“Mereka nggak mau bertema sama

kita lagi”

Subject Predicate Object Adv

Meanwhile according to

Indonesian grammatical rule the sentence should be subject - predicate - object, as follow :

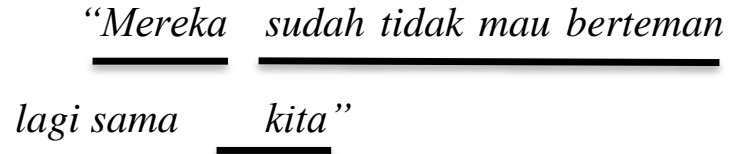

Subject Predicate Object

This error is one of the impacts of differences grammatical rule in arranging the sentence between Indonesian and $\mathrm{Li}$ Niha (Nias language). As the result, Nias speakers find some difficulties when they speak Indonesian.

Data 4 :

$\frac{\text { “Lo bisa }}{\text { Niha) Nias language }}$

Predicate Subject

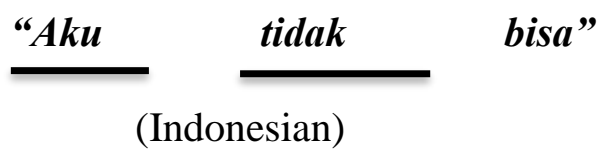

Subject Predicate 
"I can't"'

(Meaning)

Li Niha sentences seem ungrammatical when the pattern of Li Niha is brought to Indonesian. It will invert or break the rule of Indonesian grammatical structure. In $L i$ Niha, arranging the negative sentence should be predicate followed by subject (pre - subj), as follow :

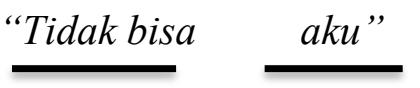

Predicate Subject

Meanwhile in Indonesian, should be subject before the predicate ( $\mathrm{subj}$ - pre), as follow :

\section{“Aku tidak bisa" \\ Subject Predicate}

Li Niha interfere Indonesian by putting the predicate first then followed by the subject. As the result, Nias speakers will invert the words (according to Nias pattern) when they are speak in Indonesian.

Data 5 :

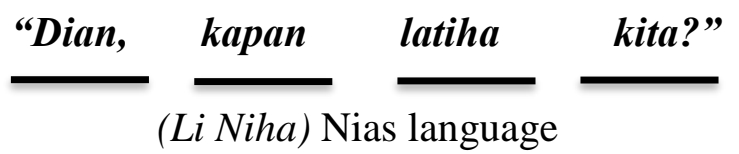

$\begin{array}{llll}\text { “Object Aux v } & \text { Verb } & \text { Subject" } \\ \text { “Dian, kapan } & \text { kita } & \text { latihan?" }\end{array}$
(Indonesian)

"Object Aux v
Verb"
"Dian, when we need to
practice?"

(Meaning)

Interrogative sentences in $\mathrm{Li}$ Niha should be auxiliary verb followed by verb then subject, meanwhile Indonesian should auxiliary verb followed by subject then verb. This difference influences Nias speakers when arrange the sentences in Indonesian. As the result, Nias speakers will interfere Indonesian as follow :

\section{"Kapan latiha kita"}

Meanwhile the sentence above is not according to Indonesian grammatical structure and the good sentence should be aux $\mathrm{v}$ - subject - verb, as follow :

"Kapan kita latihan"

Whether the sentence is understandable towards the listeners but it stills not 
accordance with Indonesian grammatical

structure and it breaks the rule.

Data 6 :

“Kapannya
pulang?"

Av Object

Verb

$\frac{\text { “Kapan }}{\text { pulang?" }} \quad \frac{\text { kamu }}{\text { (Indonesian) }}$

Av Object

Verb

"When will you come back?"

(Meaning)

Nias speakers sometimes invert the words while speaking, it is because in $L i$ Niha interrogative sentences is always begin by auxiliary verb followed by object or subject, meanwhile in Indonesian there is no absolute rule in interrogative sentences. In Indonesian it is possible to invert the structure, for example :

“Kapan kamu pulang?”

"Pulang kapan kamu?"
In Indonesian, interrogative sentences are possible to invert the grammar as long as it can be understood by the listeners but in Li Niha is not possible to invert the pattern like in Indonesian because Li Niha have their own Grammar or rule in arranging the interrogative sentences. Even though is just a simple error but still is not a good sentence according to Indonesian grammatical structure. The speaker should not bring the pattern of Nias language when speak Indonesian because it will give a negative impact such an error of grammatical. There is no other reason why Nias speakers make mistakes during the conversation or speech is because the interference of the mother tongue that leads to the error of language.

Data 7 :

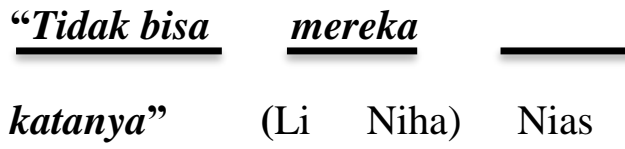

language
Adv
Object

Verb 
"Katanya

tidak bisa" (Indonesian)

Verb

Object

Adv

"They said they could not"

(Meaning)

Nias speakers get used to invert the words in a sentence, it occurs when they are speaking in Indonesian. In the sentence above, the speaker creates the sentence by using Nias pattern ( $a d v-o b j-$ verb), as follow :

"Tidak bisa mereka katanya"

Obviously, the sentence is not according to the Indonesian grammatical rule. If the sentence is in accordance with Indonesian grammatical structure, it should be (Verb Object - Adv), as follow :

"Katanya mereka tidak bisa"

In this case, the speaker interfere Indonesian by arranging the sentence with Nias pattern. As the result, Nias speakers invert the words in a sentence. There is no big deal in this error, but according to Indonesian grammatical structure the sentence is not effective at all and it sounds rambling. The speaker should pay more attention about the use of Indonesian grammatical structure, in that way the speaker is decreasing the errors. The error of grammatical structure is one of the negative impacts of Li Niha to Indonesian, and as the result Nias speakers interferes the language.

Data 8 :

$$
\begin{gathered}
\stackrel{\text { “Kan }}{\text { kalian" }} \frac{\text { baru kasih tahu }}{(\text { Li Niha) Nias language }} \\
\text { Adv Subj } \quad \text { Verb }
\end{gathered}
$$

\section{Object}

"Aku kan baru kasih tahu

kalian" (Indonesian)

Subj Adv Verb

\section{Object}

\section{"I just told you"}

(Meaning)

Nias speakers often make a simple mistake while speaking Indonesian. Just like in the sentence above, the speaker inverts the use of the adverb which actually the adverb should not in the beginning of 
the sentence. The speaker is arranging the sentence according to Nias pattern adv subject - verb - object, as follow :

"Kan aku baru kasih tahu sama kalian”

Meanwhile Indonesian grammatical structure does not agree with the sentence above, the sentence should be subject - adv - verb-object, as follow :

\section{“Aku kan baru kasih tahu kalian”}

The mistake in this sentence is not a big deal for the listeners because the sentence can be understood. Further, the error is just in the adverb which is placed in the beginning of the sentence. Therefore, the speaker needs to know the use of grammatical structure so there is no mistakes in arranging the sentence anymore. Nias speakers are difficult to follow Indonesian grammatical structure because they used to speak in Nias language. As the result, Li Niha (Nias language) influences Nias speakers when they speak Indonesian.

Data 9 :



language

$$
\text { Av Verb Object }
$$

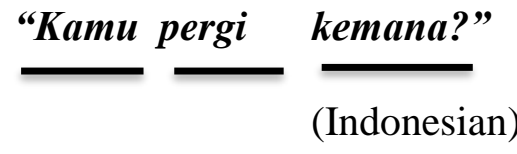

$$
\begin{aligned}
& \text { Object Verb Av } \\
& \text { "Where are you going?" } \\
& \text { (Meaning) }
\end{aligned}
$$

Nias speakers get used to use Nias pattern in arranging the sentences in Indonesian. There is no other reason behind the error of grammatical structure when Nias speakers speak in Indonesian is all because they have not master Indonesian yet. Therefore, they invert some phrases in a sentence. In the sentence above, the speaker puts auxiliary verb at the beginning of a sentence followed by verb then object which is not in accordance with Indonesian grammatical structure, as follow :

\section{“Kemana pergi kamu”}

Meanwhile the correct sentence according to Indonesian grammatical structure of interrogative sentence, should begin with 
object followed by verb then auxiliary verb, as follow :

\section{"Kamu pergi kemana"}

The error of grammatical occurs as an impact of the first language (Li Niha) which finally interfere the speaker when he or she speaks the second language (Indonesian). As the result, the speaker is difficult to speak Indonesian well.

Data 10

$\frac{\text { “dari mana }}{(\text { Li Niha })}$ Nias language
Aux v
$\frac{\text { Object }}{\text { "kamu tadi }}$
(Indonesian)
Object Auri mana"
"Where have you been"
(Meaning)

In Li Niha (Nias language) the pattern in making interrogative senetences should be auxiliary verb followed by object (aux $\mathrm{v}$ - object), as follow :



Meanwhile Indonesian grammatical rule of interrogative sentence should be object followed by auxiliary verb (object - aux v), as follow :

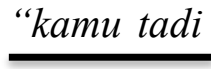

Object dari mana"

As the result, Nias speakers interfere Indonesian as their second language. In making interrogative sentence in Li Niha, it starts from auxiliary verb followed by object but in Indonesian interrogative sentences should be object followed by auxiliary verb. It may be possible to invert the object and the auxiliary verb in Indonesian interrogative sentence but nonetheless the sentence will sounds awkward if not accordance with the grammatical rule. The difference of this grammatical rule in language influences Nias speakers. They will automatically bring Nias pattern when they are speaking Indonesian. One of the errors which oftentimes occur when Nias speakers 
speak in Indonesian language is ungrammatical sentence.

Data 11

$$
\begin{aligned}
& \text { "Dikasi kue sama } \\
& \text { tadi” (Li Niha) Nias language } \\
& \text { Ket } \\
& \text { Object } \\
& \text { "Kami } \\
& \text { tadi } \\
& \text { (Indonesian) } \\
& \text { kue" } \\
& \text { Ket }
\end{aligned}
$$

\section{Object}

Obviously, Nias speakers seem like invert the word in the sentence above. It is because their mother tongue structure or the pattern in arranging the sentence is different from Indonesia grammatical structure of sentence. Commonly, in $L i$ Niha the pattern to make a sentence should be keterangan followed by object (ket object), as follow :

"Dikasi kue sama kami lo tadi"

Meanwhile, in Indonesian the sentence should be object followed by Keterangan (object $-k e t)$ as follow :

"Kami tadi di kasih kue"
This error occurs as a form impact of mother tongue towards second language. Nias speakers can't avoid the error in the time of speech, it is because the mother tongue transferring the influences automatically without awareness of the speaker.

Data 12

"Ngapai disana kamu ba" (Li Niha) Nias language

Aux v Ket Object

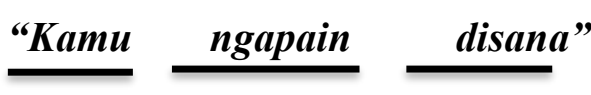

(Indonesian)

Object Aux v Ket

"What are you doing there?"

(Meaning)

Nias speakers oftentimes invert the word when they speak in Indonesian. No other reason behind this error, it is because they got influences by their mother tongue (Nias language). The difference structure between the languages (Nias language and Indonesian) become a big impact for Nias speakers when they speak in their second language. In the sentence, the pattern in 
making the sentence should be auxiliary verb followed by keterangan then followed by object (aux v-ket-object) as follow :

\section{"Ngapai disana kamu ba?"}

Meanwhile, the sentence above is not accordance with Indonesian grammatical rule. It should be object followed by auxiliary verb then followed by keterangan (object - aux $\mathrm{v}-\mathrm{ket}$ ) as follow:

"Kamu ngapain disana" or

"Ngapain kamu disana"

The second phrase above is also possible (aux $\mathrm{v}-$ object $-k e t)$ because it still accordance with Indonesian grammatical rule, the sentence still in a good formation and easy to be understood by the listener. So, Nias speakers got influences by their mother tongue and ended with interference.

\section{Data 13}

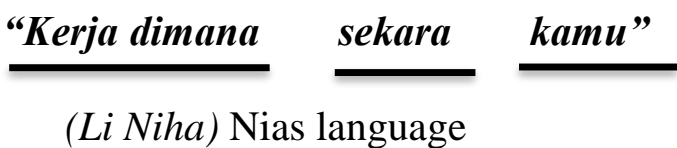

$$
\text { Ket Object }
$$

“Kamu kerja dimana sekarang”

(Indonesian)

Object

Aux v

Ket

"Where do you work now?"

(Meaning)

In the sentence above, it obvious that Nias speakers invert the words. The speaker arranging the sentence by used Nias pattern meanwhile is not a Nias language. The sentence formed with Auxiliary verb followed by Ket the followed by object (aux v - ket - object) as follow :

"Kerja dimana sekarang kamu”

Meanwhile, in Indonesian the sentence should be object followed by auxiliary verb then followed by ket (object - aux v ket) as follow :

"Kamu kerja dimana sekarang" or "Sekarang, kamu kerja dima"

As long as the sentence can be understood by the listener, the error must be not a big deal for the speaker.

Data 14 
“Tida mau kesana aku"

(Li Niha) Nias language

Predicate Ket Subject

“Aku $\underset{\text { (Indonesian) }}{\text { tidakmau }}$ kesana”

Subject Predicate Ket

"I don't want to go there"

(Meaning)

Nias speakers get used to invert the words in a sentence, it occurs when they are speaking in Indonesian. In the sentence above, the speaker make the sentence by using Nias pattern; predicate followed by subject then followed by keterangan (Predicate $-k e t-$ subject) as follow :

"Tida mau kesana aku"

Meanwhile, the sentence above is not accordance with Indonesian grammatical rule. The sentence should be subject followed by predicate then followed by keterangan (subject - predicate - ket) as follow :

"Aku tidak mau kesana"

In the sentence above, we can see if the structure between the two languages ( $\mathrm{Li}$
Niha and Indonesia) is different. It is become a reason for Nias speakers to cause some interference. The error occurs as a form of an impact which is brought by the speaker from mother tongue to second language. In this case, the listener may be know what the speaker meant but still the sentence is not in a good formation according to Indonesian rule.

Data 15

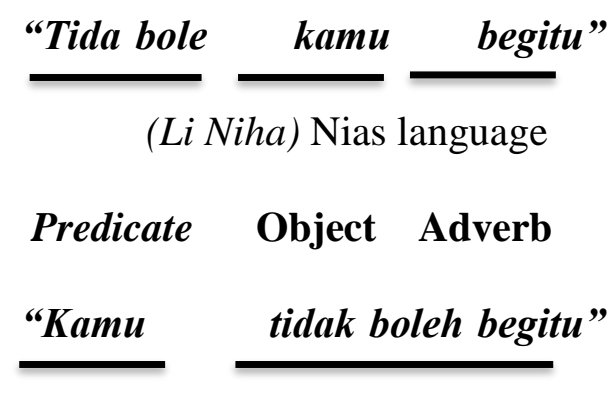

(Indonesian)

\section{Object Predicate}

"Don't be like that"

(Meaning)

To make a sentence in Li Niha should be predicate followed by object then followed adverb (predicate - object adverb) as follow :

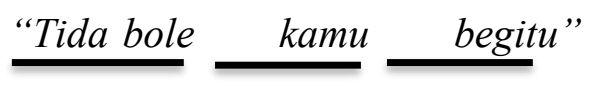

Predicate Object Adverb 
Meanwhile, to make a sentence in Indonesia should be object followed by predicate (object - predicate) as follow :

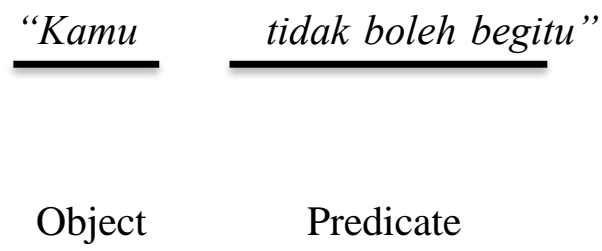

The differences grammatical rule between Li Niha and Indonesian gives some difficulties towards Nias speakers. As the result of this difference, Nias speakers invert the word and make the sentence ungrammatical according to Indonesian grammatical structure. The sentence may be understandable towards the listener but still the sentence is not in a good formation.

\section{Conclusion}

As discussed previously, interference of language is one of the speak error which is considered as the referring of damaging the system language. Language interference is the effect of language learners on their production of the language they are learning, means that the first language of the speaker influences their second language. Through the data that has been found by the writer, it proves that Nias speakers have got negative impact or influence by their mother tongue, Li Niha (Nias language). As the result, Nias speakers interfere Indonesian language. Some interferences of Nias speakers that have been found in Indonesian, are :

1. Phonological Interference ; Omission of Final Consonant.

2. Syntactical Interference; Redundancy and Grammatical Structure.

Based on the data and the analysis above, it proves that Nias' first language gives negative impact towards Indonesian.

\section{References}

Abrego Martínez, et all. 2013. The Level Of Interference of English Learners'Mother Tongue with Their Learning Of Prepositions. El Salvador University. San Salvador.

Apeli, Charity U. 2013. Journal of Language Phonological Interference in the Spoken English Performance of the Izon Speaker in 
Nigeria: A Product of Systemic and Interlanguage Factors. Ethiopia.

Archvadze, Ekaterine. The Problems of First Language Interference in the Process of Teaching Second Languages. Journal. Tsereteli State University. Georgia.

Brown, Pamela Leanne. 2001. A Grammar of Nias Selatan. Sidney University. Sidney.

Chambers J. K. 1995. Sociolinguistic Theory; Linguistic Variation and its Social Significance. Toronto University. USA.

Ellis, Rod. 1997. The study of second language acquisition. Oxford: Oxford University Press.

Supriyanto, Ranto Asti.-. Grammatical Interference from English into Indonesian Language Made by English Native Speakers in Salatiga. STAIN. Salatiga

Kridalaksana, Harimurti. 1984. Kamus Linguistik. Jakarta : PT. Gramedia.

Krashen, S. D. 1981. Second Language Acquisition and Second Language learning. Oxford : Pergamon.

Luo, Jianping. 2014. A Study of Mother Tongue Interference in Pronunciation of College English Learning in China. Guangdong University: Petrochemical Technology. China.

Lott. 1983. Interference Language Transferi Interlingual Errors in Spanish Students of English as a Foreign Language. Spain: Universidad de Santiago de Compostela.
Mackey, William F. 1970. Interference, Integration, and the Synchronic Fallacy. International Center of Bilingualism. Laval University. Canada.

Mahsun. 2007. Metode Penelitian Bahasa : Tahapan, strategi, metode, dan tekhniknya. Jakarta : Raja Grafindo Persada.

Martanti, Putri. 2011. Mother-Tongue Interference on English Language Pronunciation of Senior Primary School Pupils in Nigeria: Implications for Pedagogy. Islam Negeri University. Jakarta.

Maros, Marlyna. 2007. Interference In Learning English: Grammatical Errors In English Essay Writing Among Rural Malay Secondary School Students In Malaysia. Journal. University Kebangsaan Malaysia. Malaysia.

Muhammad. 2011. Metode Penelitian

Bahasa. Jogjakarta: Ar - ruzz Media.

Nazir, Moh. 2006. Metode Penelitian. Jakarta: Ghalia Indonesia.

Patrick, Judith Makse, Ph.D. Scholar, M.Ed. English Education, et all. 2013. Mother-Tongue Interference on English Language Pronunciation of Senior Primary School Pupils in Nigeria: Implications for Pedagogy. Nigeria.

Radhika V. and Kala Mary Surya. 2013. Interference of Mother Tongue in Learning a Foreign Tongue. International electronic journal for the teachers of English.

Ritchie Jane and Lewis Jane. 2003. Qualitative Research Practice. 
SAGE Publication. London, Thousand Oaks, New Delhi. file:///C:/Users/Evi/Downloads/Do cuments/qualitative-researchpractice a-guide-for-socialscience-students-andresearchers jane-itchie-and-janelewis-eds_20031.pdf, June $19^{\text {th }}$ 2016.

Sari, Dewi Permata. 2011. An Analysis Of Grammatical Interference In Interview Session of Puteri Indonesia 2009 On Miss Universe Contest 2010. Journal. Islam Negeri University. Jakarta.

Semi, Atar. 1993. Metode Penelitian Sastra. Bandung : Angkasa

Sudaryanto. 1993. Metode dan Aneka Tehnik Analisis Bahasa (Pengantar Penelitian Wahana Kebudayaan secara Linguistik). Yogyakarta : Duta Wacana University Press.

Suharsimi Arikunto. 2006. Prosedur Penelitian: Suatu Pendekatan Praktik. Jakarta: PT Rineka Cipta 